\title{
Pancreatic islet expression profiling in diabetes-prone C57BLKS/J mice reveals transcriptional differences contributed by DBA loci, including Plagll and Nnt
}

\author{
Abraham A Anderson*1, Joan Helmering2, Todd Juan ${ }^{3}$, Chi-Ming Li ${ }^{3}$, \\ Jocelyn McCormick², Melissa Graham², Daniel M Baker ${ }^{4}$, \\ Michael A Damore ${ }^{4}$, Murielle M Véniant ${ }^{2}$ and David J Lloyd ${ }^{2}$
}

Address: ${ }^{1}$ Department of Computational Biology, Amgen Inc., One Amgen Center Dr, Thousand Oaks, CA 91320, USA, ${ }^{2}$ Department of Metabolic Disorders, Amgen Inc., One Amgen Center Dr, Thousand Oaks, CA 91320, USA, ${ }^{3}$ Department of Protein Sciences, Amgen Inc., One Amgen Center Dr, Thousand Oaks, CA 91320, USA and 4 Department of Molecular Sciences, Amgen Inc., One Amgen Center Dr, Thousand Oaks, CA 91320, USA

Email: Abraham A Anderson* - andersoa@amgen.com; Joan Helmering - jlofing@amgen.com; Todd Juan - tjuan@amgen.com; ChiMing Li - chimingl@amgen.com; Jocelyn McCormick - jocelynm@amgen.com; Melissa Graham - mgraham@amgen.com;

Daniel M Baker - bakerd@amgen.com; Michael A Damore - mdamore@amgen.com; Murielle M Véniant - mveniant@amgen.com; David J Lloyd - dlloyd@amgen.com

* Corresponding author

Published: 22 January 2009

PathoGenetics 2009, 2:1 doi:10.1/86/1755-8417-2-1
Received: 4 November 2008

Accepted: 22 January 2009

This article is available from: http://www.pathogeneticsjournal.com/content/2/I/I

(c) 2009 Anderson et al; licensee BioMed Central Ltd.

This is an Open Access article distributed under the terms of the Creative Commons Attribution License (http://creativecommons.org/licenses/by/2.0), which permits unrestricted use, distribution, and reproduction in any medium, provided the original work is properly cited.

\begin{abstract}
Background: C57BLKS/J (BLKS) mice are susceptible to islet exhaustion in insulin-resistant states as compared with C57BL6/J (B6) mice, as observed by the presence of the leptin receptor (Lepr) allele, Leprdb/db. Furthermore, DBA2/J (DBA) mice are also susceptible to $\beta$-cell failure and share $25 \%$ of their genome with BLKS; thus the DBA genome may contribute to $\beta$-cell dysfunction in BLKS mice.

Results: Here we show that BLKS mice exhibit elevated insulin secretion, as evidenced by improved glucose tolerance and increased islet insulin secretion compared with B6 mice, and describe interstrain transcriptional differences in glucose response. Transcriptional differences between BLKS and B6 mice were identified by expression profiling of isolated islets from both strains. Genomic mapping of gene expression differences demonstrated a significant association of expression differences with DBA loci in BLKS mice $\left(P=4 \times 10^{-27}\right)$.

Conclusion: Two genes, Nicotinamide nucleotide transhydrogenase (Nnt) and Pleiomorphic adenoma gene like I (Plag/I), were 4 and 7.2-fold higher respectively in BLKS islets, and may be major contributors to increased insulin secretion by BLKS islets. Contrary to reports for B6 mice, BLKS mice do not harbor a mutant Nnt gene. We detected 16 synonymous polymorphisms and a twoamino acid deletion in the Plagl/ gene in BLKS mice. Several inflammatory glucose-responsive genes are expressed at a higher level in BLKS, suggesting an inflammatory component to BLKS islet dysfunction. This study describes physiological differences between BLKS and B6 mice, and provides evidence for a causative role of the DBA genome in $\beta$-cell dysfunction in BLKS mice.
\end{abstract}




\section{Background}

Type 2 diabetes mellitus can be considered as a two-stage disease. First the body becomes resistant to circulating insulin, and second, when coupled with pancreatic $\beta$-cell dysfunction, overt diabetes precipitates [1]. Insulin resistance alone, without $\beta$-cell exhaustion, will not lead to hyperglycemia. In this case the islet compensates by increasing insulin production and $\beta$-cell populations are maintained. Differences in $\beta$-cell adaptation to increased insulin demand likely reflect an underlying genetic component. Indeed, in B6 mice, but not in genetically dissimilar BTBR mice, insulin resistance induced by the leptin $o b$ allele is well compensated by islet expansion [2]. The genetic alteration in BTBR mice which underpins this failure to adapt to increased insulin requirements was recently identified and localized to a gene contributing to islet vascularization [3].

Obese (Lepr $\left.{ }^{\mathrm{db} / \mathrm{db}}\right)$ B6 and 129/J mice are insulin resistant but compensate this potentially pathogenic process by islet hypertrophy and hyperinsulinemia [4,5]. However, obese $(L e p r \mathrm{db} / \mathrm{db})$ DBA mice not only develop insulin resistance but also severe diabetes due to $\beta$-cell loss. Thus the DBA background may be considered a diabetogenic strain exhibiting a predisposition to $\beta$-cell failure. DBA mice copiously secrete insulin (10-fold over basal) in response to a glucose bolus compared with a modest (3fold) increase in B6 mice [6]. This hypersecretion phenotype (here after referred to as elevated insulin secretion) is retained in isolated islets, and confirms a functional difference between these two strains specific to the islet. These data suggest that elevated secretion of insulin may be deleterious to the $\beta$ cell and results in $\beta$-cell exhaustion in DBA mice.

BLKS mice also exhibit pancreatic islet failure when made insulin resistant by the ob or $d b$ Lepr alleles $[5,7,8]$, as evidenced by gross islet atrophy and $\beta$-cell loss. This strain is closely related to B6; however, it harbors a small contribution from the DBA strain. Genetic analysis of the BLKS mice has uncovered a contribution of approximately $71 \%$ from B6, 25\% from DBA, and 4\% from other strains in BLKS mice [9-11]. Given the clear differences in severity of diabetes between B6-Lepr $\mathrm{db} / \mathrm{db}$ mice and BLKS-Lepr $\mathrm{db} / \mathrm{db}$ mice, and the similarity between BLKS and DBA mice, it is tempting to speculate that islet sensitivity may be conferred by alleles from the DBA genome.

In this report we investigated islet function in non-obese B6 and BLKS mice. We found that BLKS mice are profoundly more glucose tolerant than $\mathrm{B} 6$ and this difference was associated with elevated secretion of insulin in islets. We investigated the differences in gene expression in isolated islets between the two strains, in both basal and stimulated (insulin secretion stimulated) conditions, and found that $75 \%$ of the gene expression differences in the BLKS islets were contributed from genes within DBA loci. Further, several genes regulated by glucose in both strains suggest early inflammatory effects associated with increased glucose (Txnip,Lnc2,Gad1 Slc7a3 and Spp1). Notably, we identified significantly higher expression of Nnt and Plagl1 (ZAC1) in BLKS islets, two genes previously associated with islet dysfunction.

\section{Results and discussion}

Glucose homeostasis in non-obese BLKS and B6 mice

Although glucose homeostasis has been extensively studied in BLKS-Lep $\mathrm{db} / \mathrm{db}$ mice, few reports have shown clear differences in non-obese BLKS mice compared with B6 mice. To better understand the differences between both these strains, we analyzed fasting glucose in young (12 weeks old) and aged (26 weeks old) mice. At 12 weeks of age, fasting glucose levels between $\mathrm{B} 6$ and BLKS mice were similar $(113.3 \pm 5.7 \mathrm{mg} / \mathrm{dL}$ vs. $100.7 \pm 3.6 \mathrm{mg} / \mathrm{dL}$, respectively) as well as at 26 weeks $(118.4 \pm 4.2 \mathrm{mg} / \mathrm{dL} v s .111 .0$ $\pm 17 \mathrm{mg} / \mathrm{dL}$ ). Interestingly, B6 mice and BLKS mice have similar body weights at younger ages but after 16 weeks of age the $\mathrm{B} 6$ mice continue to gain weight whereas BLKS mice do not (Figure 1A). Also, in 12-week-old-mice insulin levels were the same in the two strains (Figure 1B). However, at 26 weeks B6 mice had significantly higher insulin levels $(P=0.018)$ than BLKS mice, and could reflect the difference in body weights. We found no differences in glucagon levels (data not shown). The difference in insulin levels in older mice may also represent a difference in glucose homeostasis. To investigate this further, glucose tolerance tests (GTTs) were performed at 10 and 23 weeks of age (Figure $1 \mathrm{~B}$ ). At both ages, glucose tolerance between B6 and BLKS mice was clearly different. Although 10-week-old B6 and BLKS mice had similar basal fasting blood glucose levels, at 30,60 and $120 \mathrm{~min}$ after an intraperitoneal injection of glucose $\mathrm{B} 6$ mice were less glucose tolerant than the BLKS mice. Similar results were obtained at 23 weeks of age; however, at this age the basal fasted blood glucose values for the BLKS mice were statistically lower than the B6 mice. Both lines of mice were more glucose intolerant at 23 weeks than at 10 weeks of age (blood glucose spike at $30 \mathrm{~min}$ was increased in both strains). The glucose intolerance observed in the B6 mice at 23 weeks could be related to the higher body weight and some degree of peripheral of insulin resistance. On the other hand, the younger B6 and BLKS 10week-old mice had similar body weights yet clearly were dissimilar in glucose tolerance; furthermore, a report by Goren et al [12] illustrated that 8 to 10-week-old B6 and BLKS mice are very similar when challenged in an insulin tolerance test. Taken together, we interpret these data to reflect a pancreatic difference between these two strains to account for the differences in glucose tolerance. 
A

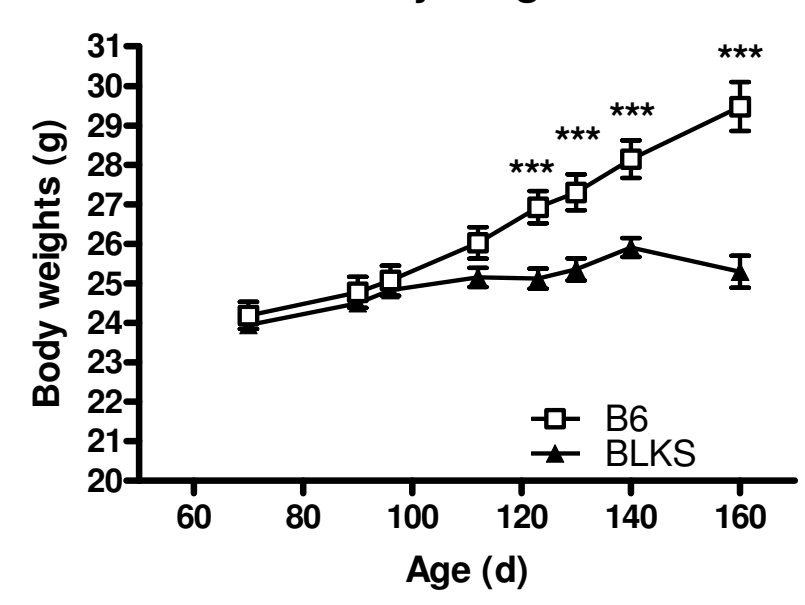

C
B

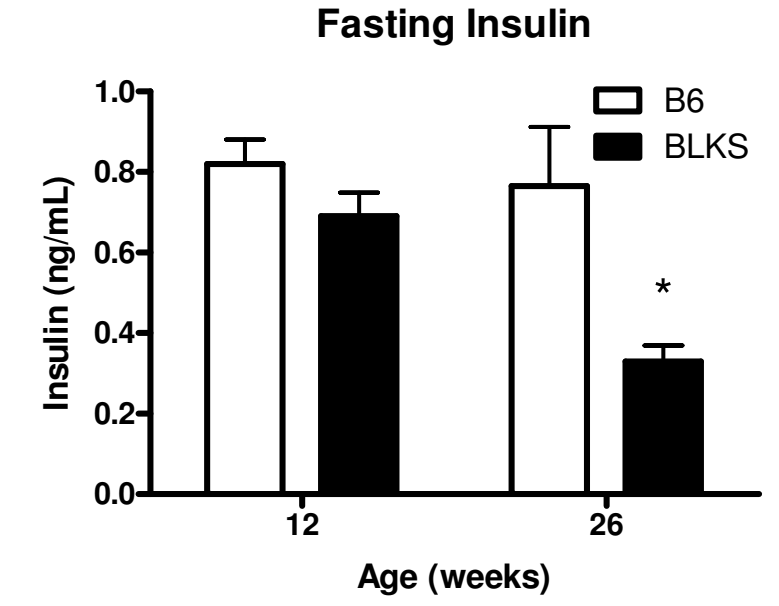

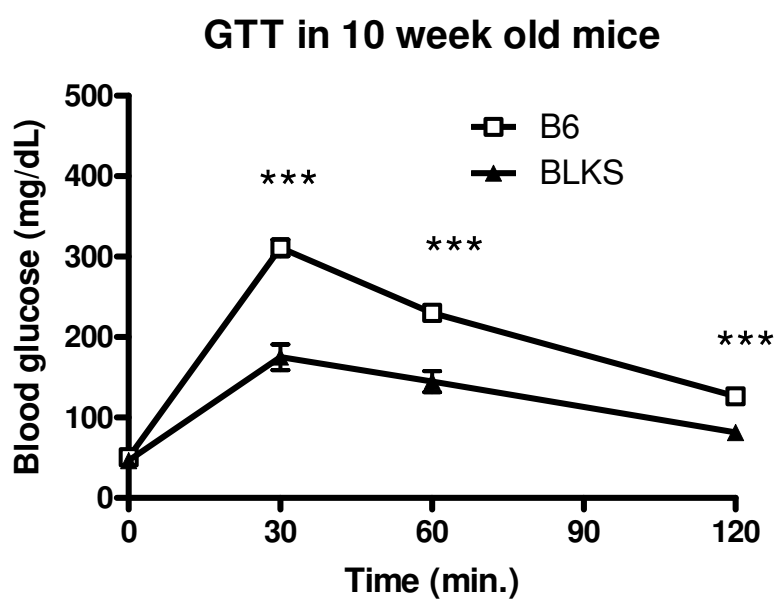

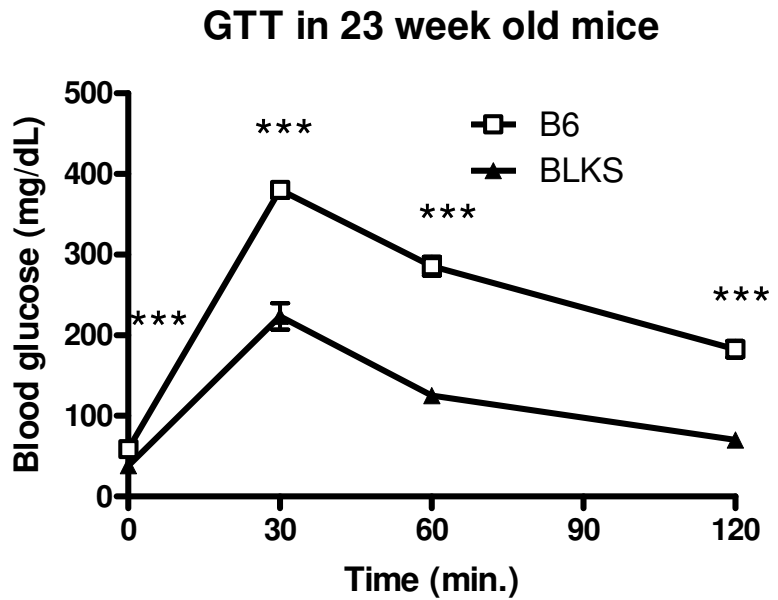

Figure I

Glucose homeostasis in B6 and BLKS mice. (A) Body weights of B6 and BLKS male mice ( $n=13$ for each strain) were monitored from 10 weeks to 26 weeks of age. (B) Fasting $(4 \mathrm{~h})$ plasma insulin was analyzed in 10-week $(n=13)$ and 23 -week $(n$ = 8) -old B6 and BLKS male mice. (C) Glucose tolerance was assessed in 10 and 23-week-old B6 and BLKS male mice, following an intraperitoneal injection of glucose $(2 \mathrm{~g} / \mathrm{kg})$. All data represent means and s.e.m. and tested using a two-tailed Student's $T$ test assuming unequal variances; $* P<0.05, * * P<0.01$, $* * * * 0.001$.

Islet insulin secretion and pancreatic immunohistochemistry

To investigate if the enhanced glucose clearance in BLKS mice was attributed to increased insulin secretion, glucose-stimulated insulin secretion was measured in isolated islets from both B6 and BLKS mice (Figure 2A). Islets of BLKS mice secreted significantly more insulin than B6 mice at the higher glucose concentrations tested, providing further support for an elevated secretion phenotype.
These data have been shown for DBA mice [6,13], but to date have not been reported for BLKS mice.

To determine if the difference in insulin secretion correlated with differences in $\beta$-cell mass, we performed histology and immunohistochemistry on pancreatic sections from both strains. No gross differences in islet number or appearance were observed in either B6 or BLKS mice as assessed in multiple mice of each strain. Furthermore, fol- 
A

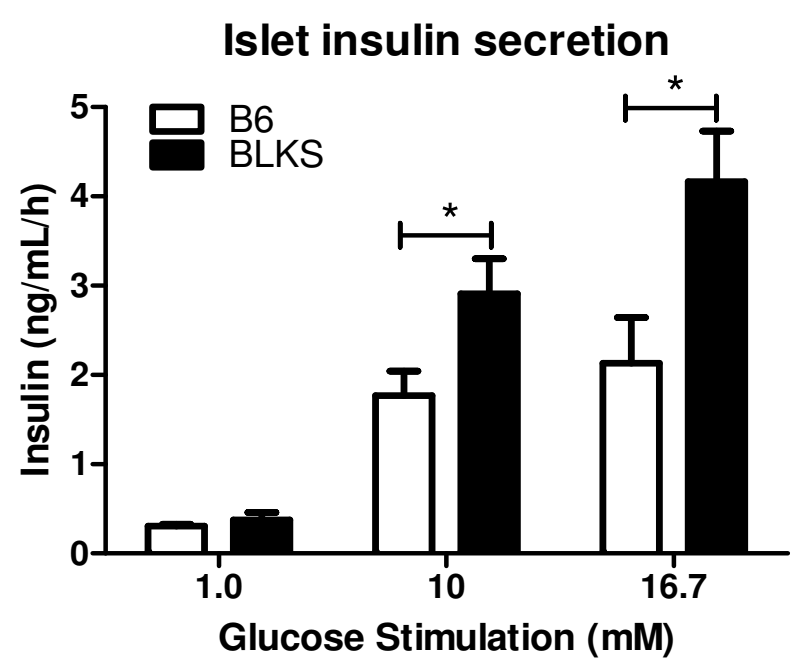

B

C
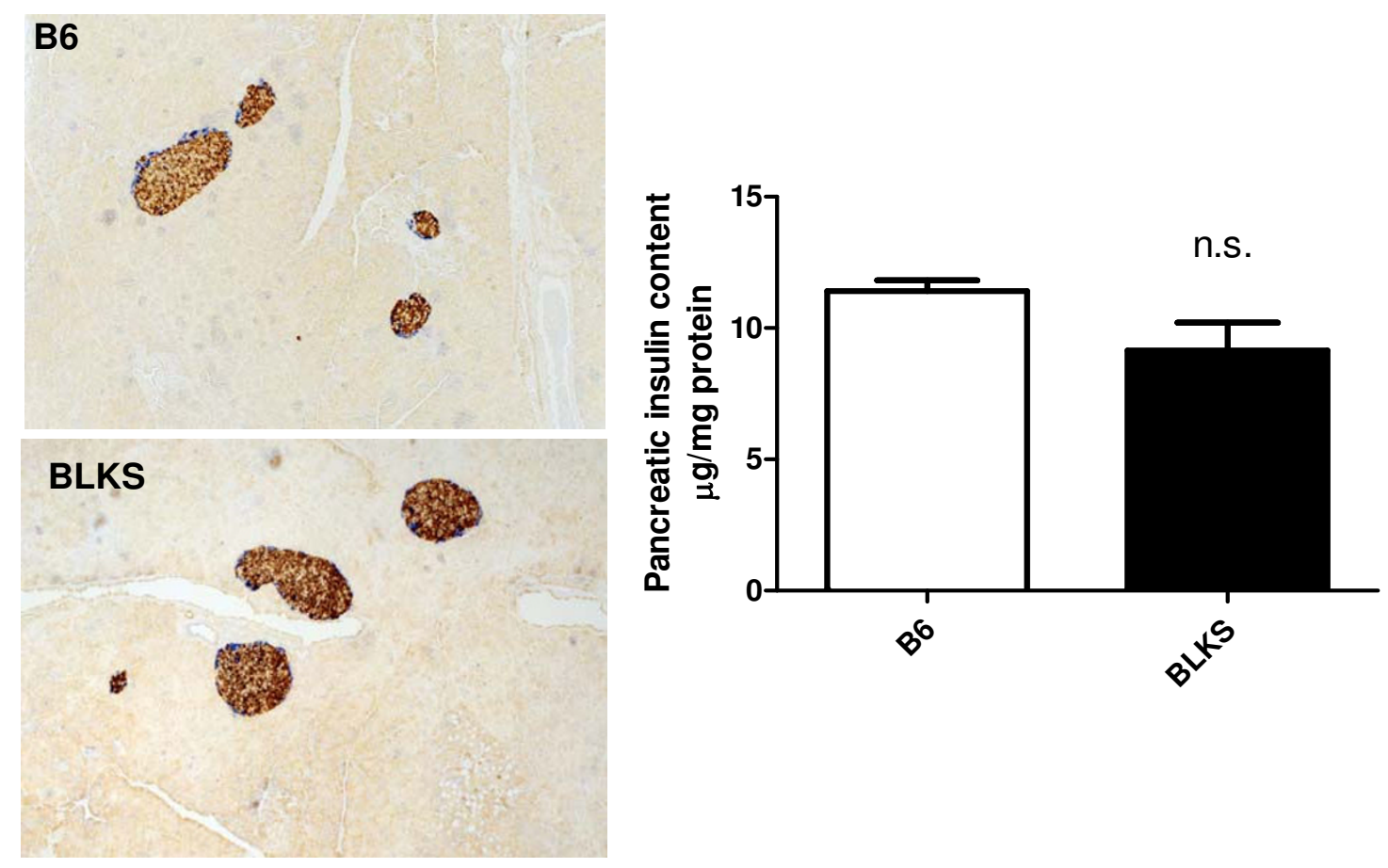

Figure 2

Insulin secretion is higher in BLKS mice than B6 mice. (A) Glucose-stimulated insulin secretion was investigated in isolated islets from 12-week-old B6 and BLKS male mice. Following $48 \mathrm{~h}$ recovery post-isolation, the islets were stimulated with 2, 10 or $16.7 \mathrm{mM}$ glucose for I h. Insulin release into the media was monitored. (B) Immunohistochemistry was performed in pancreatic islets from 26-week-old male mice revealing no gross differences in islet appearance or size. Insulin (oxidized DABbrown) and glucagon (Vector Blue product) expressing cells are shown. (C) Pancreatic insulin content was assessed in pancreata excised from 15-week-old male B6 and BLKS mice $(n=3 /$ group). No statistically significant differences were detected. All data represent means and s.e.m. and tested using a two-tailed Student's $T$-test assuming unequal variances; $* P<0.05 ;$ n.s. not significant. 
lowing staining for insulin and glucagon, a similar composition of $\alpha$ and $\beta$ cells within the islet was found (Figure $2 \mathrm{~B})$. Thus the difference in insulin secretion was not associated with any qualitative difference in $\beta$-cell mass. To investigate if any quantitative differences in $\beta$-cell mass were present between the two strains, we analyzed pancreatic insulin content (Figure 3C). Pancreata from BLKS mice were found to have a small but non-significant reduction in pancreatic insulin content compared with B6 mice. This, however, is unlikely to explain the elevated insulin secretion observed in the BLKS mice.

\section{Islet gene expression differences between glucose concentrations}

Given that islet dysfunction is a characteristic of BLKS-Lep$r \mathrm{db} / \mathrm{db}$ mice but not of B6-Lepr $\mathrm{db} / \mathrm{db}$ mice, and is associated with heightened insulin secretion in non-obese BLKS mice, we hypothesized that these physiological outcomes may be reflected in differences in islet gene expression. We investigated gene expression in normal (non-diabetic) mice with the intention of analyzing expression in islets with similar compositions of $\alpha, \beta$, and $\delta$ cells. Furthermore, we speculated differences in gene expression may only become apparent after a period of extended secretion, which would expose genes involved in islet dysfunction/adaptation. To this end, islets were isolated from 10 B6 and 10 BLKS mice, and cultured for 2 days in $11 \mathrm{mM}$ glucose (each individual mouse's islets were cultured separately). After this period, islets from five $\mathrm{B} 6$ mice were cultured in $5 \mathrm{mM}$ glucose and from five B6 mice in $20 \mathrm{mM}$ glucose for an additional $24 \mathrm{~h}$. BLKS islets were treated similarly. RNA isolated from each individual mouse's islets was used to investigate global changes in gene expression between the strains in low and high-glucose conditions. We assessed the common differences due to glucose concentration (Table 1), and differences between strains (Table 2).

Table 1 shows gene expression fold-change differences between low and high-glucose conditions in BLKS and B6 mice. We highlight the subset with BLKS glucose response of at least 2-fold. These transcriptional differences associated with glucose response in islets suggest an underlying inflammatory component. Lipocalin 2 (Lcn2) transcription increases 2.4-fold in response to higher glucose levels and is 2.07-fold higher in BLKS islets. This gene is regulated by the cytokine leptin in insulinoma cells [14] and interestingly BLKS mice also have $40 \%$ more of a specific leptin receptor (Leprotl1) at high glucose levels - 1.44 and 1.09-fold under high and low-glucose conditions, respectively. $L c n 2$ is also known to be up-regulated in rat models of type 2 diabetes, and associated with inflammatory functions [15] including apoptosis. The glucose-responsive gene Glutamate decarboxylase 1 (Gad1), which is an islet-derived autoantigen in insulin-dependent diabetes
[16], may be a marker for $\beta$-cell loss or toxicity and has been shown to be glucose responsive. We observed a Gad1 decrease in both mouse models, but more so in the BLKS mice. The gene with the largest change due to glucose in BLKS mice was S100a9. This gene is expressed in monocytes and pancreatic cell lines, and is essential for pancreatic leukocyte infiltration $[17,18]$. In addition to being an inflammatory marker S100a9 is associated with islet autoimmunity [19]. Another glucose-responsive gene, Slc7a3, is likely an indirect marker for the presence of resident islet inflammatory cells. $S l c 7 a 3$ is a polar amino acid transporter, which provides L-arginine that can be used in nitric oxide (NO) production. NO synthesis and overproduction has been associated with $\beta$-cell dysfunction in diabetic rats [20].

In addition to the inflammation-associated genes we also observed strong induction by glucose of the gene encoding Thioredoxin interacting protein (Txnip) in both BLKS and B6 mice. Txnip has been recently linked with glucoseinduced $\beta$-cell loss [21]. Chen et al showed that glucose incubation up-regulated Txnip and increased apoptosis, which they speculated may be via the intrinsic mitochondrial apoptotic pathway. They also showed that constitutive over-expression is not necessary for apoptosis, but that the glucose-induced increase is sufficient. Furthermore, Parikh et al have shown that, in humans, Txnip over-expression reduces basal and insulin-stimulated glucose uptake [22], is elevated by glucose and suppressed by insulin. We confirm the increase of Txnip expression in response to glucose, although we do not observe any differential response to glucose between B6 and BLKS mice. On the contrary, BLKS mice have 2-fold lower levels of Txnip than B6 mice. Thus Txnip is unlikely to underlie the islet failure in BLKS mice, but more likely to represent the typical response to glucose.

\section{Islet gene expression differences between B6 and BLKS strains}

Table 2 shows a list of genes which were more than 2.5fold different in BLKS islets compared with B6 islets in high glucose conditions (column 4, High Gluc.). All members of this list were significantly different between strains, regardless of glucose concentration, after controlling the false discovery rate at 0.80 [23]. In addition to its induction by glucose within each strain (Table 1) Spp1 expression is also significantly different between strains and is 3.5-fold higher in BLKS islets (Table 2). Spp1 or osteopontin is a multifunctional cytokine and a potential diagnostic predictor of diabetic end-stage renal disease [24]. Arafat et al have shown that Spp1 averts cytokinemediated $\beta$-cell toxicity through negative regulation of NO production [25]. As we have shown, both BLKS and B6 mice up-regulate Slc7a3, a gene associated with NO production, but BLKS mice always express higher levels 
A

\section{Plagl1 islet expression}

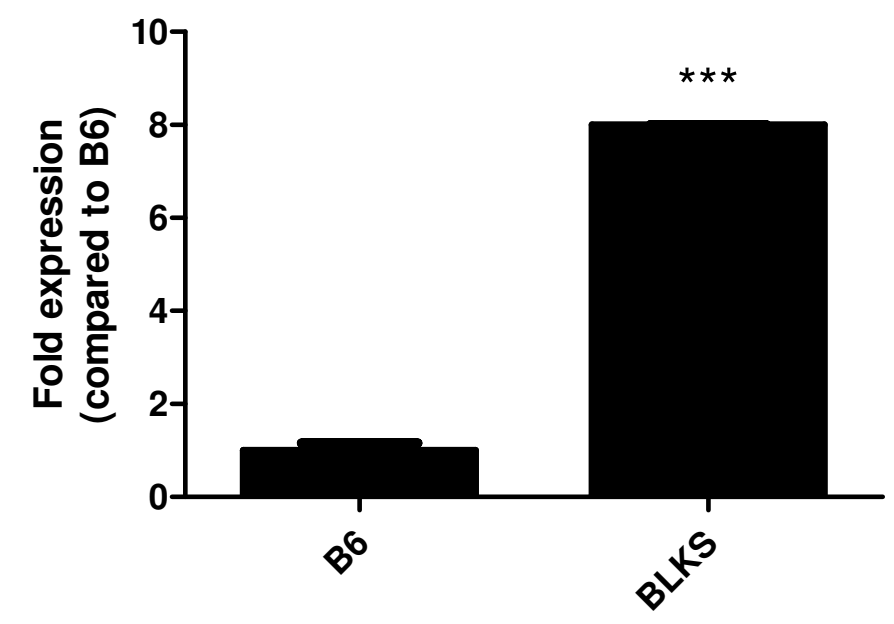

B

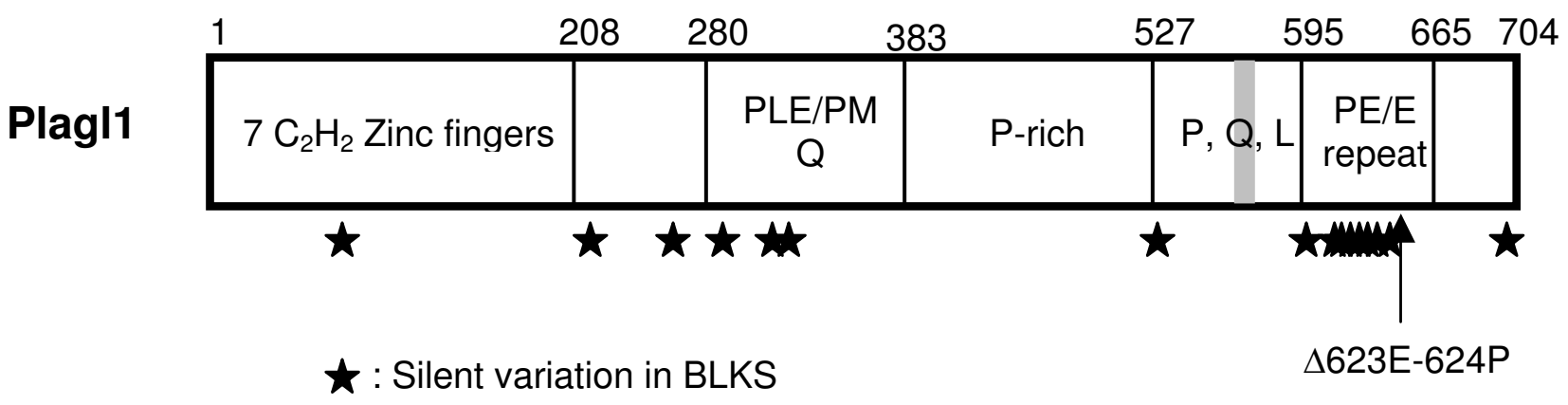

Figure 3

Plagll expression and genetic differences in BLKS mice. (A) Quantitative RT-PCR analysis of the Plagllt RNA in B6 and BLKS in isolated islet cultured in high glucose conditions. Data represent means and standard deviations of multiple mice (B6 $n$ $=8$; BLKS $n=4$ ) and tested using a two-tailed Student's T-test assuming unequal variances; *** $P<0.00 \mathrm{I}$. (B) Diagram of the polypeptide structure of Plagl I identifying the functional domains. Numbers refer to the mouse amino-acid positions, and letters refer to amino acids. The genetic differences between B6 and BLKS genes are shown by the stars; the two-amino acid deletion in BLKS is shown by the arrow. 
Table I: Gene expression fold-change differences in islets from low to high glucose in BLKS and B6 mice

\begin{tabular}{|c|c|c|c|c|c|c|}
\hline \multirow[t]{2}{*}{ Probe } & \multirow[t]{2}{*}{ Gene } & \multirow[t]{2}{*}{ Description } & \multicolumn{2}{|c|}{ Interstrain fold difference (BLKS/B6) } & \multicolumn{2}{|c|}{ Glucose response (fold change) } \\
\hline & & & Low Gluc. & High Gluc. & B6 & BLKS \\
\hline A_5I_P402943 & SIO0A9 & S100 calcium-binding protein A9 & 1.21 & 3.28 & 1.59 & 4.31 \\
\hline A_5I_P438805 & TXNIP & thioredoxin-interacting protein & -1.72 & -2.01 & 4.16 & 3.56 \\
\hline A_5I_P358765 & SPPI & secreted phosphoprotein I & 2.46 & 3.76 & 2.12 & 3.24 \\
\hline A_5I_P2750I6 & SLC7A3 & solute carrier family 7 member 3 & 1.49 & 1.97 & 2.13 & 2.82 \\
\hline A_5I_P372550 & CGREFI & $\begin{array}{l}\text { cell growth regulator with EF-hand } \\
\text { domain I }\end{array}$ & 1.04 & 1.65 & 1.76 & 2.79 \\
\hline A_5I_P5I0I56 & LCN2 & lipocalin 2 & 1.98 & 2.07 & 2.31 & 2.41 \\
\hline A_52_P94482 & TTYHI & tweety homolog I & 1.73 & 1.84 & 2.23 & 2.37 \\
\hline A_5I_PI94I49 & TTR & transthyretin & $-1.3 \mid$ & 1.13 & 1.59 & 2.37 \\
\hline A_5I_P428384 & TTYHI & tweety homolog I & 1.58 & 2.19 & 1.70 & 2.36 \\
\hline A_52_P326399 & FKBPII & FK506-binding protein II & 1.50 & 1.48 & 2.39 & 2.36 \\
\hline A_5I_PI30727 & FKBPII & FK506-binding protein II & 1.65 & 1.64 & 2.34 & 2.33 \\
\hline A_5I_P227275 & CSN3 & casein kappa & 1.43 & 1.54 & 2.15 & 2.31 \\
\hline A_5I_P370458 & A030006PI6RIK & RIKEN cDNA & 1.01 & 1.64 & 1.41 & 2.29 \\
\hline A_5I_P391955 & $2310032 F 03 R I K$ & RIKEN cDNA & 1.10 & 1.21 & 2.07 & 2.27 \\
\hline A_5I_P346938 & LRGI & leucine-rich alpha-2-glycoprotein I & 1.18 & 1.17 & 2.22 & 2.20 \\
\hline A_52_PI87058 & NPTX2 & neuronal pentraxin II & 1.67 & 2.38 & 1.51 & 2.16 \\
\hline A_5I_P4359II & HSD3B7 & $\begin{array}{l}\text { hydroxy-delta-5-steroid } \\
\text { dehydrogenase, } 3 \text { beta- and steroid } \\
\text { delta-isomerase } 7\end{array}$ & 1.17 & 1.69 & 1.46 & 2.11 \\
\hline A_5I_PI62955 & SERPINA7 & serpin peptidase inhibitor member 7 & -1.01 & 1.21 & 1.69 & 2.07 \\
\hline A_52_P547328 & TRAMI & $\begin{array}{l}\text { translocation-associated membrane } \\
\text { protein I }\end{array}$ & 1.09 & 1.51 & 1.49 & 2.06 \\
\hline A_5I_P272876 & FAM46A & $\begin{array}{l}\text { family with sequence similarity } 46 \text {, } \\
\text { member A }\end{array}$ & 1.59 & 1.72 & 1.88 & 2.03 \\
\hline A_52_PI443I0 & GADI & glutamate decarboxylase I & 1.02 & -1.23 & -1.63 & -2.04 \\
\hline A_5I_PI99352 & $23100 I 5 B 20 R I K$ & RIKEN cDNA & -1.25 & -1.71 & -1.62 & -2.21 \\
\hline
\end{tabular}

Genes are sorted for the subset with BLKS glucose response (fold change) $>2(p<0.00$ I, Benjamini-Hochberg FDR 0.8). 
Table 2: Gene expression fold-change differences in islets from BLKS mice compared with those from B6 mice

\begin{tabular}{|c|c|c|c|c|c|c|c|}
\hline \multirow[b]{2}{*}{ Probe } & \multirow[b]{2}{*}{ Gene } & \multirow[b]{2}{*}{ Description } & \multicolumn{2}{|c|}{ Interstrain fold difference (BLKS/B6) } & \multirow[b]{2}{*}{ Chromosome } & \multirow[b]{2}{*}{$\mathrm{Mb}$} & \multirow[b]{2}{*}{ Genetic Origin } \\
\hline & & & Low Gluc. & High Gluc. & & & \\
\hline A_5I_P4I725I & 6330403K07RIK & RIKEN cDNA & 4.32 & 17.43 & $\mathrm{II}$ & 71.1 & DBA \\
\hline A_52_P532456 & PLAGLI & $\begin{array}{l}\text { pleiomorphic adenoma gene- } \\
\text { like I }\end{array}$ & 2.93 & 7.15 & 10 & 12.8 & DBA \\
\hline A_5I_PII3395 & NNT & $\begin{array}{l}\text { nicotinamide nucleotide } \\
\text { transhydrogenase }\end{array}$ & 1.94 & 4.22 & 13 & 116.6 & DBA \\
\hline A_52_P395228 & NNT & $\begin{array}{l}\text { nicotinamide nucleotide } \\
\text { transhydrogenase }\end{array}$ & 2.01 & 4.07 & 13 & 116.6 & DBA \\
\hline A_5I_PII3399 & NNT & $\begin{array}{l}\text { nicotinamide nucleotide } \\
\text { transhydrogenase }\end{array}$ & 1.79 & 3.85 & 13 & 116.6 & DBA \\
\hline A_5I_P422030 & FLJ22709 & hypothetical protein & 1.99 & 3.82 & 8 & 69.8 & DBA \\
\hline A_5I_P358765 & SPPI & secreted phosphoprotein I & 2.46 & 3.76 & 5 & 103.6 & B6 \\
\hline A_5I_P253984 & PCP4 & Purkinje cell protein 4 & 1.93 & 3.52 & 16 & 96.9 & DBA \\
\hline A_5I_P402943 & S100A9 & $\begin{array}{l}\text { SI00 calcium-binding protein } \\
\text { A9 }\end{array}$ & 1.21 & 3.28 & 3 & 90.8 & DBA \\
\hline A_52_P542860 & BTBD9 & BTB domain-containing 9 & 1.99 & 3.27 & 17 & 28.7 & DBA \\
\hline A_5I_P440682 & CAPI & $\begin{array}{l}\text { CAP, adenylate cyclase- } \\
\text { associated protein I }\end{array}$ & 1.82 & 3.17 & 4 & 122.3 & DBA \\
\hline A_52_P3029 & AGPAT4 & $\begin{array}{l}\text { I-acylglycerol-3-phosphate O- } \\
\text { acyltransferase } 4\end{array}$ & 1.42 & 2.92 & 17 & 10.9 & DBA \\
\hline A_5I_P323620 & THYNI & thymocyte nuclear protein I & 1.74 & 2.91 & 9 & 26.9 & other \\
\hline A_5I_P346I65 & AGPAT4 & $\begin{array}{l}\text { I-acylglycerol-3-phosphate O- } \\
\text { acyltransferase } 4\end{array}$ & 1.42 & 2.89 & 17 & 10.9 & DBA \\
\hline A_5I_PII84I7 & SCPEPI & serine carboxypeptidase I & 1.70 & 2.87 & 11 & 89.0 & DBA \\
\hline A_5I_P454873 & NPY & neuropeptide $Y$ & 1.97 & 2.72 & 6 & 49.8 & B6 \\
\hline A_5I_P49I0I7 & GNPTG & $\begin{array}{l}\mathrm{N} \text {-acetylglucosamine-I- } \\
\text { phosphate transferase, gamma } \\
\text { subunit }\end{array}$ & 1.82 & 2.71 & 17 & 23.4 & DBA \\
\hline A_52_P748882 & ENO2 & enolase 2 & 1.62 & 2.58 & 6 & 124.8 & DBA \\
\hline A_5I_PI67535 & FABP3 & fatty acid-binding protein 3 & 1.88 & 2.53 & 4 & 129.8 & DBA? \\
\hline A_5I_PI30028 & ENO2 & enolase 2 & 1.63 & 2.53 & 6 & 124.8 & DBA \\
\hline A_5I_PI0I545 & HGFAC & HGF activator & -1.92 & -2.54 & 5 & 34.1 & DBA \\
\hline A_5I_P337269 & $A L D O B$ & $\begin{array}{l}\text { aldolase } B \text {, fructose- } \\
\text { bisphosphate }\end{array}$ & -1.17 & -2.66 & 4 & 49.6 & B6 \\
\hline
\end{tabular}


Table 2: Gene expression fold-change differences in islets from BLKS mice compared with those from B6 mice (Continued)

\begin{tabular}{|c|c|c|c|c|c|c|c|}
\hline A_5I_P2I5627 & PLAC9 & placenta-specific 9 & -1.89 & -2.67 & 14 & 23.6 & $\overline{\text { DBA }}$ \\
\hline A_52_P644774 & ZZEFI & $\begin{array}{l}\text { zinc finger, ZZ-type with EF- } \\
\text { hand domain I }\end{array}$ & -1.92 & -2.73 & 11 & 73.0 & DBA \\
\hline A_5I_P5I7075 & SERPINFI & $\begin{array}{l}\text { serpin peptidase inhibitor, } \\
\text { clade } \mathrm{F} \text { member I }\end{array}$ & -1.50 & -2.78 & 11 & 75.5 & DBA \\
\hline A_52_P2I 3889 & TMC7 & transmembrane channel-like 7 & -1.87 & -2.83 & 7 & 114.5 & DBA \\
\hline A_52_P6I3498 & $4833420 G I 7 R I K$ & RIKEN cDNA & -2.04 & -3.01 & 13 & 116.7 & DBA \\
\hline A_5I_P376656 & SYNPR & synaptoporin & -2.13 & -3.08 & 14 & 11.4 & DBA \\
\hline A_52_P50496 & HLA-A & $\begin{array}{l}\text { major histocompatibility } \\
\text { complex, class I, A }\end{array}$ & -2.23 & -3.16 & 17 & 32.1 & DBA \\
\hline A_5I_P50996I & SLC5AIO & $\begin{array}{l}\text { solute carrier family } 5 \\
\text { member } 10\end{array}$ & -1.21 & -3.24 & 11 & 61.8 & DBA \\
\hline A_5I_P246677 & REC8LI & REC8-like I & -2.28 & -3.61 & 14 & 50.5 & DBA \\
\hline A_5I_P3925I8 & THUMPDI & THUMP domain-containing I & -2.83 & -4.30 & 7 & 115.6 & DBA \\
\hline A_5I_PI46560 & MSLN & mesothelin & -2.31 & -4.36 & 17 & 23.9 & DBA \\
\hline A_52_PI37500 & AK046255 & Unknown cDNA & -2.70 & -5.06 & $x$ & 131.8 & DBA \\
\hline A_5I_P443443 & 58304 I $7 I I O R I K$ & RIKEN cDNA & -2.75 & -5.46 & 3 & 89.0 & DBA \\
\hline A_52_P23I729 & $\mathrm{H} 2-\mathrm{QI}$ & $\begin{array}{l}\text { major histocompatibility } \\
\text { complex Q Ib }\end{array}$ & -8.74 & -29.31 & 17 & 33.4 & DBA \\
\hline
\end{tabular}

Shown is the subset with fold change $>2.5$ under high glucose conditions $(p<0.00$ I, Benjamini-Hochberg FDR 0.8$)$. Genes are sorted by the interstrain fold difference in high glucose conditions.

(1.49 to 1.97 -fold). Thus, the excess capacity for NO production in BLKS mice might counter the protective up-regulation of Spp1. Other genes such as S100a9, Aldob, and Slc5a10 demonstrate a stronger glucose response in only one of the mouse strains. S100a9, a diabetes-associated pro-inflammatory molecule [26], had a much larger increase due to increasing glucose in BLKS mice (4.3-fold) vs. B6 mice (1.6-fold). Aldob, encoding a glycolytic enzyme that is decreased in human diabetic islets [27], and Slc5a10, a sodium/glucose co-transporter, had stronger induction due to increasing glucose in $\mathrm{B} 6$ mice (1.5 and 3.5-fold respectively) vs. BLKS mice (1.1 and 1.6fold respectively).

From Table 2, 32 genes were more than 2.5-fold different in expression levels in BLKS islets compared with B6 islets; 16 genes were expressed at higher levels and 16 genes expressed at lower levels. Thirty of these genes displayed fold differences with magnitudes between 2.5 and 7.15. However, two genes had notable differences above this range.
The first, an uncharacterized transcript (6330403K07RIK), was 17.4-fold higher in BLKS islets. At this time, this gene's product has no assigned function and has no known homology to any protein. Interestingly, two protein sequences were identified from the NCBI gene database corresponding to 6330403K07RIK which had been translated from DBA genomic sequence and B6 mRNA sequence and were found to be different. The protein sequence from DBA mice (AAR87485) was different at four residues compared with the $\mathrm{B} 6$ sequence (BAB31072) over the 121 residues.

The second gene with profound differential expression was H2-Q1, with a 29.3-fold lower level in the islets from BLKS mice. H2-Q1 localizes to the H2 locus in mice on chromosome 17. $\mathrm{B} 6$ mice are known to be isogenic for the H2b haplotype and BLKS mice are a recombinant congenic strain carrying the H2d haplotype [28]. The difference in H2-Q1 expression likely represents a difference conferred by the two haplotypes, and the H2-Q1 gene is possibly not expressed in mice with the $\mathrm{H} 2 \mathrm{~d}$ haplotype. 
Furthermore, another gene from the H2 locus was identified in Table 2 (H2-K1), and suggests that the influence of $\mathrm{H} 2$ haplotype can manifest in multiple gene expression differences.

In further studies, we focused on the two genes Plagl1 and $N n t$, which have previously been implicated in islet dysfunction in both humans and mice.

\section{Transcriptional differences in Plagll and Nnt}

The second-most highly expressed gene in BLKS islets compared with B6 islets was Plagl1 (7.2-fold higher expression; Table 2). The expression state and magnitude was confirmed by qRT-PCR under the same conditions of high glucose in a separate experiment (Figure 3A). Plagl1 has been previously implicated in human transient neonatal diabetes mellitus (TNDM) [29], and can result from paternal uniparental disomy of chromosome 6 , or paternal duplication of 6q24 (the TNDM locus). These genetic aberrations suggest the disease results from over-expression of an imprinted gene [29]. If BLKS islets are indeed predisposed to failure (when confronted with insulin resistance), then over-expression of Plagl1 would be consistent with the expression observed in human TNDM. Similarly, mice which over-express the human TNDM locus (including Plagl1) exhibit impaired glucose homeostasis [30]. Several functions for Plagl1 have been reported [31]. Interestingly, evidence that Plagl1 can regulate apoptosis may be relevant to the $\beta$-cell dysfunction in these mice. In BLKS mice, the Plagl1 gene is within a locus predicted to be inherited from the DBA parental strain. To investigate the underlying cause for the difference in Plagl1 expression we sequenced the four exons of the gene. Contrary to the published DNA sequence of Plagl1 in B6 mice, BLKS mice have 16 synonymous polymorphisms and a two-amino acid deletion (623Glu-624Pro; Figure $3 \mathrm{~B}$ ). These polymorphisms are contained within the third exon of the gene. The 16 synonymous polymorphisms may not affect the function of the protein, but could perhaps contribute to the higher expression of the Plagl1 transcript by affecting RNA stability. Additionally the 6 bp deletion could alter the RNA stability or possibly change the function of the protein product. The $623 \mathrm{Glu}-$ 624Pro deletion in BLKS mice lies at the end of a repetitive Pro-Glu-Gln repeat region not found in the human paralog. Despite this structural difference within the Plagl1 gene of human and mice, functional differences have not been observed [31]. Thus it is uncertain whether the deletion of the 623Glu-624Pro is functionally relevant to the $\beta$-cell phenotype in BLKS mice.

We observed three different probes for Nnt that all showed a clear difference in expression (Table 2). On average, the Nnt was expressed at 4 -fold higher levels in BLKS islets in high-glucose conditions. It was observed that the differences in Nnt expression were present in islets cultured in low-glucose conditions (Table 2, column 4); however, this was greater in islets following a stimulated pretreatment. B6 mice were recently shown to be glucose intolerant, as a result of impaired insulin secretion, and this was linked to mutation of the Nnt gene [32]. In this study, a quantitative trait locus (QTL) analysis in $\mathrm{B} 6$ and $\mathrm{C} 3 \mathrm{H} / \mathrm{HeH}$ mice revealed that expression of $\mathrm{Nnt}$ was 5 -fold lower in B6 islets, and is similar with the 4-fold level we observed compared with BLKS islets. Nnt is a nuclearencoded mitochondrial protein involved in detoxification of reactive oxygen species [33], which is crucial for their removal and to reduce their deleterious effect on mitochondrial ATP production. Intact Nnt will likely lead to higher ATP levels and thus enhanced insulin secretion in the $\beta$ cell. To confirm the role of Nnt in insulin secretion, B6 mice were rescued with an Nnt transgene which improved the insulin secretion [34]. Furthermore, in vitro analyses using insulin-secreting Min6 cells and isolated islets with reduced $N n t$ function demonstrated diminished insulin secretion associated with lower ATP levels [35]. An intact Nnt gene might be expected to lead to higher ATP levels in BLKS $\beta$ cells and thus increased insulin secretion.

To investigate the origin of the Nnt gene in BLKS mice, we first investigated its genomic location at $116.1 \mathrm{Mb}$ on chromosome 13 and found that this locus was predicted to be derived from the DBA parental genome [9], suggesting that the gene in BLKS mice was intact. Next, we sequenced the first coding exon, previously reported to contain a point mutation in B6 mice [32]. In DBA mice, codon 35 reads ATG, resulting in methionine, whereas in B6 mice this codon is ACG, resulting in threonine. We found that the DBA strain contributed this exon of the Nnt gene in BLKS mice due to the presence of the ATG at codon 35 (Figure 4A). B6 mice also have a deletion of exons 8 to 11 in this gene [32]. To confirm that the BLKS mice did not carry this multi-exon deletion we performed RT-PCR on islet RNA with primers spanning the deletion (Figure 4B). Corresponding to the intact gene from DBA mice, a 1497 bp amplicon was generated from the DNA of BLKS mice, whereas in B6 mice a smaller 743 bp fragment was observed, as expected, due the deletion. We also observed two smaller fragments of 402 and 598 bp in B6, and inspection of the gene sequence suggests that these fragments are likely a result of the mis-splicing of exon 7 to exons 13 and 14. Altogether, these data show that Nnt is contributed by the DBA strain in BLKS and is intact, in contrast to the disrupted $\mathrm{B} 6$ gene. Thus, the higher islet expression of Nnt in BLKS mice relative to the $\mathrm{B} 6$ mice is most likely due to the lack of mutation in the DBAderived allele, and may lead to higher ATP levels and higher insulin secretion, accounting for the enhanced glucose tolerance. Recently a study was published identifying 


\section{Thr}

A
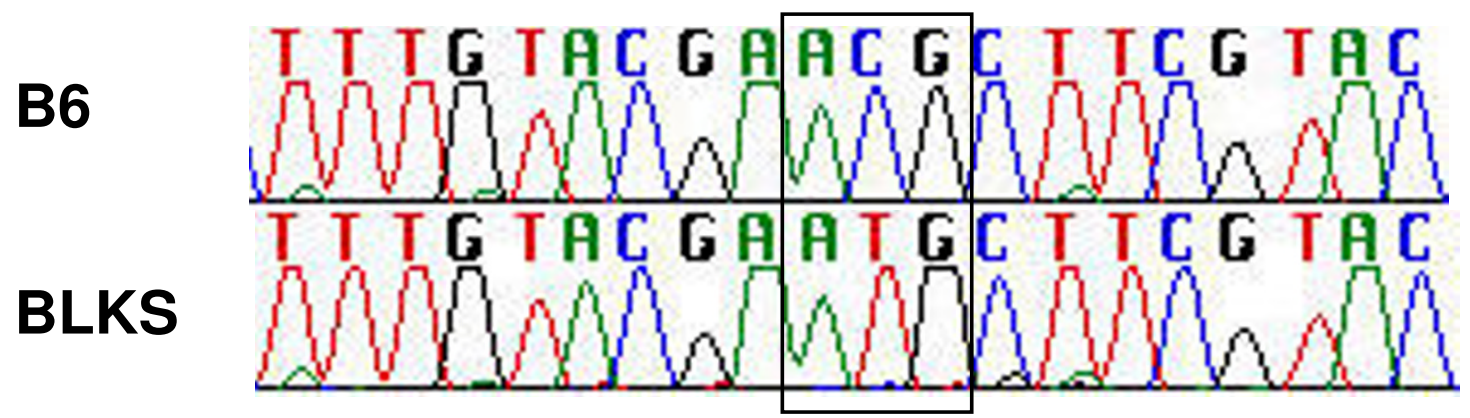

Met

B

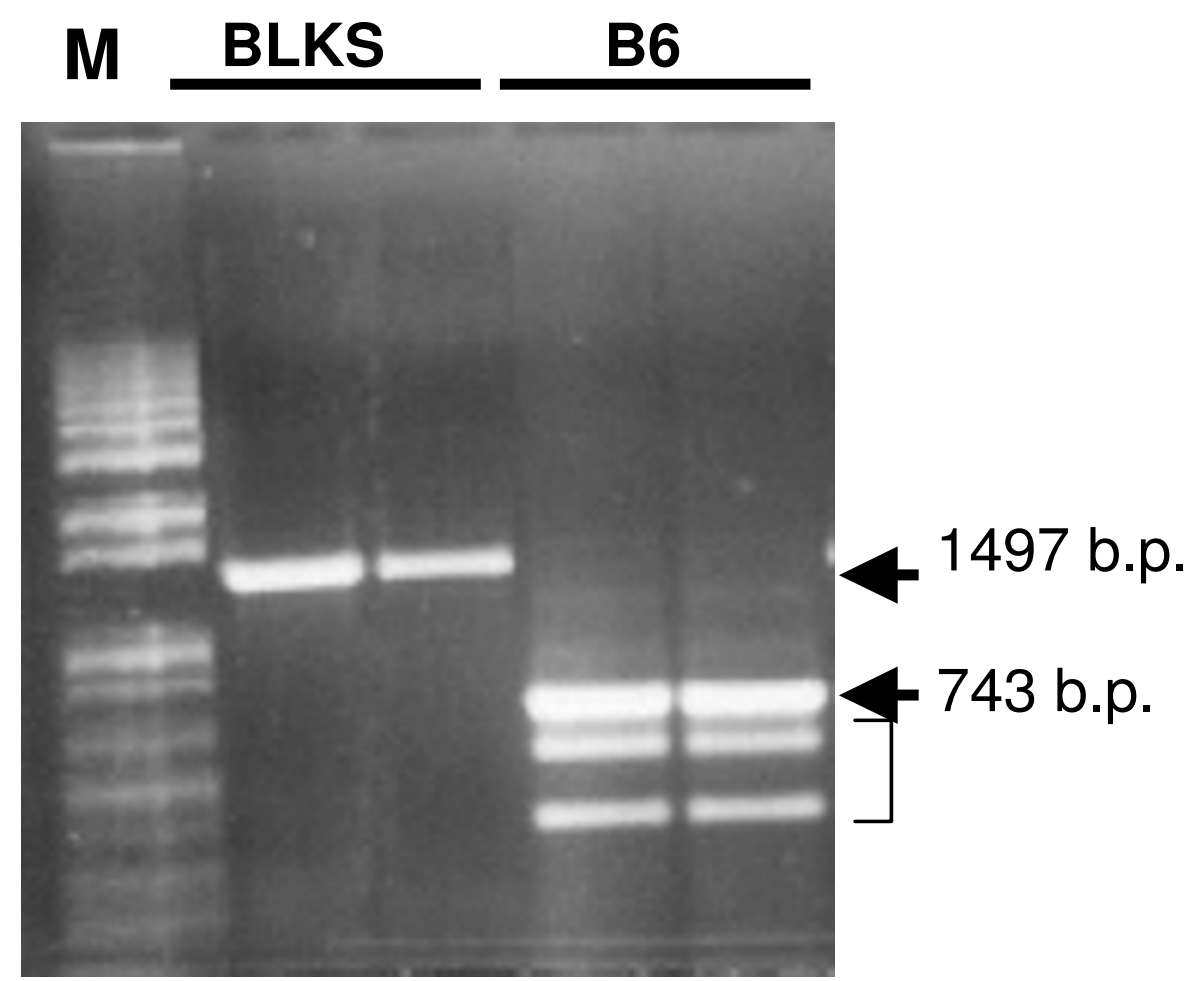

Figure 4

Nicotinamide nucleotide transhydrogenase is derived from the DBA strain in BLKS mice. (A) Sequencing of exon I of the Nnt gene in BLKS and B6 mice confirms the DBA origin of the gene in the BLKS genome. B6 mice possess the codon for threonine (Thr) at residue 35, whereas the BLKS mice have the codon for methionine (Met). (B) RT-PCR analysis of the Nnt RNA in B6 and BLKS. A smaller RT-PCR fragment is amplified from B6 RNA (743 bp) than BLKS RNA ( 7998 bp), confirming the deletion of exons 8 to II previously described in B6 mice [32]. The two smaller bands (bracket) in B6 mice are likely mis-splicing artifacts from downstream exons which are flanked by the PCR primers. M - marker. 
a strong QTL on chromosome 13 governing insulin hypersecretion in a B6 $\times$ DBA cross [36]. Nnt was identified as the likely candidate gene and higher gene expression and intact gene structure was observed in islets. These data support our results and confirm the fact that Nnt gene is inherited from the DBA genome in BLKS mice.

The observations of altered expression of Plagl1 and Nnt between these two strains could account for the phenotypic differences observed in insulin-resistant states, such as enforced by deficiency of leptin or its receptor. Their individual prior association with human and/or mouse diabetes suggest these genes are functionally relevant to the proper action or survival of the $\beta$ cell. The expression differences of these two genes alone may possibly be sufficient to elicit a physiological effect through their interaction. Indeed, the elevated secretion of insulin expected in $\beta$ cells with intact Nnt function may precipitate an apoptotic event in a pro-apoptotic, Plagl1-enriched cell.

\section{Expression differences are mainly contributed by the DBA loci}

We hypothesized that the DBA genome contributes to the islet dysfunction. The locations of the DBA blocks in the BLKS genome have been mapped by other groups [9-11]. We noticed that Plagl1 and Nnt were located in DBA loci of the BLKS genome, and investigated the genetic origin of the other genes in Table 2 . We found that 28 out of these 32 genes were derived from DBA loci (Table 2, last three columns), based on the genetic mapping of Davis et al [9].

We extended these observations of genomic location and expression fold change to the entire genome. Using the published mapping data [9] we identified the B6, DBA, and Other loci. Other loci were informative regions, but not classifiable as either B6 or DBA. Within these loci we mapped all the probes used in the profiling experiment and combined these data (Additional file 1, supplemental figure). All of the probes were segregated into genome sets, based on location of parental genomes (as described for Additional file 1, supplemental figure). Not all probes could be mapped and were labeled as unmapped, due to the inability to assign probes in intervals between markers derived from different strains. Figure 5 shows the fold changes of the probe sets from the B6, DBA and Other genomes. Microarray probes appear to be uniformly distributed across the mouse genome, and among the haplotype blocks. As the threshold increases, the contribution of the $\mathrm{B} 6$ genome declines, and no differences above a threshold of 3.5 were detected (Figure 5). In contrast to the $\mathrm{B} 6$ contribution, the contribution of the DBA genome increases as the fold change cut-off increases. At a 2-fold change or greater cut-off, we observed that $75 \%$ of the probes were DBA in origin, representing 10 times as many B6 probes. Furthermore, these data show a contribution of the Other genome within the range of 2 to 4-fold; up to $23 \%$ of the probes with a fold change greater than or equal to four are from genes located in the Other genome.

We used the Kruskal-Wallis test to determine if there was a statistical difference in global gene expression foldchange distributions between probes from the different genomes. At the level of the whole genome, we found there was very high statistical significance for fold-change differences between DBA, B6 and Other $\left(\chi^{2}=126.52, P<\right.$ $4 \times 10^{-27}$, for probes with significant $\left[P<1 \times 10^{-6}\right]$ fold changes). We also investigated each chromosome individually using the same test, and found that many chromosomes showed significant differences in fold change between block types (Additional file 1, supplemental table). Chromosomes 6, 7, 8, 13 and 17 were all significant for fold-change distribution differences between the genomes. These data indicate an association of the DBA loci with the gene expression differences in BLKS mouse islets. In a QTL screen to identify loci which influence metabolic phenotypes between B6 and BLKS mice, Mu and colleagues [37] identified two suggestive LOD scores for plasma glucose on chromosomes 8 and 17, both identified in our study to harbor significant gene expression differences. Additionally, the recent report by AstonMourney and co-workers [36] identified suggestive LOD scores for insulin secretion on chromosomes 5, 6 and 7, of which two were identified in our study.

\section{Conclusion}

We have analyzed the physiological differences between B6 and BLKS mice with attention to their glucose homeostasis/islet phenotype. We have shown several transcriptional differences linked to diabetes and inflammatory mechanisms leading to islet damage. Glucose stimulation appears to elicit inflammatory responses, and particularly increases in the genes Lcn2, Spp1, S100a9, and Slc7a3. These changes are seen in both strains, but expression is always higher in BLKS mice. Altogether this suggests that islet dysfunction in BLKS has a strong inflammatory component. The largest islet gene expression differences were in Plagl1 and Nnt, two genes implicated in $\beta$-cell biology. We identified genetic differences in these genes between the two strains. The interaction of these two genes may account for the $\beta$-cell dysfunction commonly observed in BLKS mice. Lastly, we undertook a genomic approach to translate islet expression data, and revealed a significant and primary contribution from the DBA genome. These data demonstrate the utility of combining genomic, genetic, and physiological data to aid in the delineation of multi-factorial phenotypes. 
Fold Change Distribution

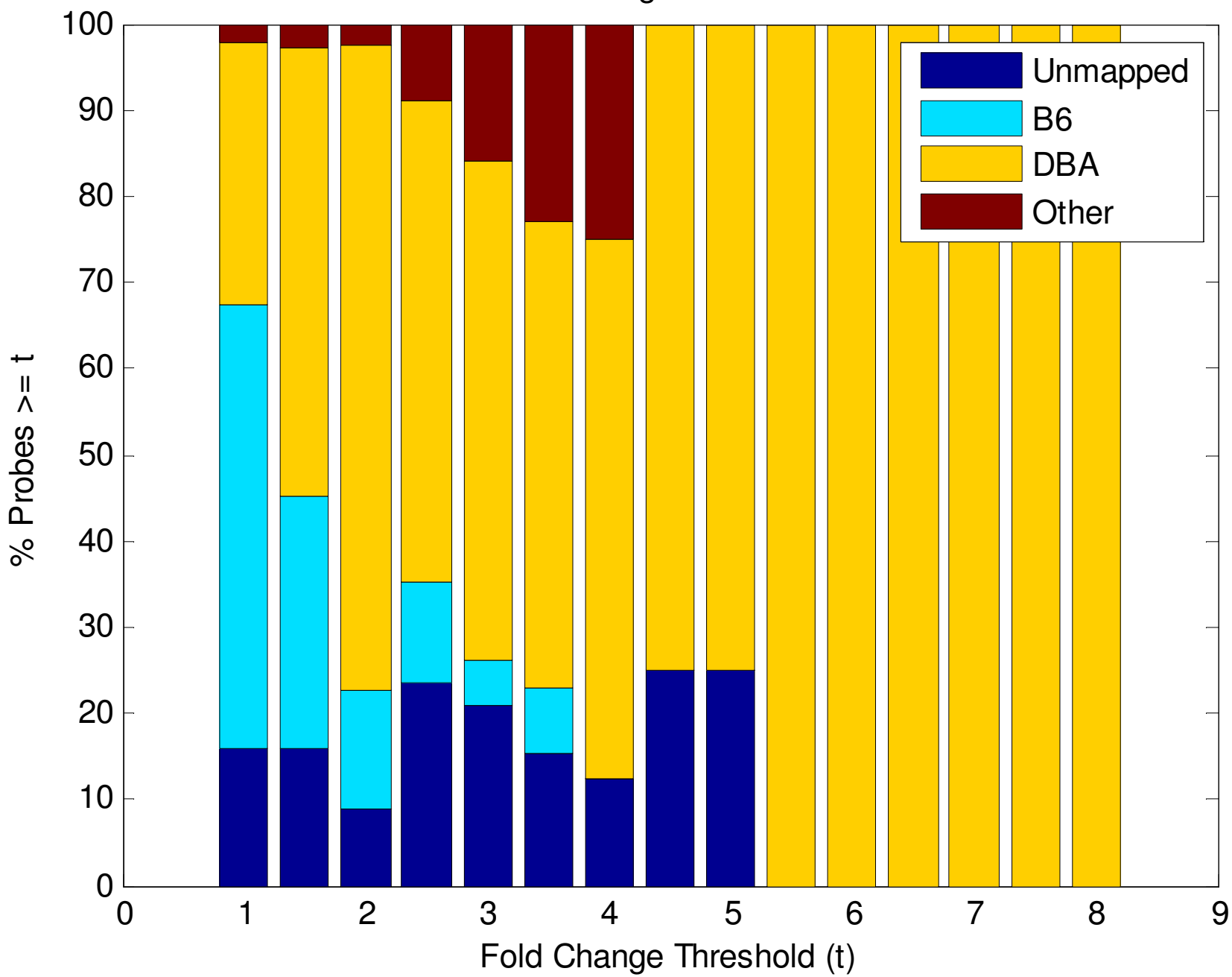

Figure 5

Gene expression differences in BLKS islets demonstrate a major contribution by DBA located probes. Gene expression fold-change differences for all probes in the experiment were assigned to either B6, DBA or Other genomes based on chromosomal location. The percentage of probes greater than the fold change threshold $(t)$ are plotted against $t$ for each set of genomically assigned probes. The contributions at a threshold of I reflect the baseline genomic contribution of these probes. As the fold change threshold increases, the B6 differences sharply decline, whereas the DBA probes increase their contribution. Above a fold change of 4.5 , all of the expression differences are accounted for by DBA assigned probes.

\section{Methods}

\section{Animal studies}

All mice were maintained in accordance with the Institutional Animal Use and Care Committee of Amgen Inc. B6 and BLKS male mice were obtained at 6 weeks of age from The Jackson Laboratory (Bar Harbor, ME). Mice received food and water ad libitum and were maintained on a 12:12 h light-dark cycle (lights on at 6:30 am) and housed one per cage. Fasting $(4 \mathrm{~h})$ blood samples $(150 \mu \mathrm{l})$ were collected from the retro-orbital sinus of non-anesthetized mice into EDTA plasma tubes and blood glucose was measured using a OneTouch Profile glucometer (LifeScan, Milpitas, CA). For GTT, mice were fasted from 9:00 pm to 9:00 am. Blood glucose was measured at 9:00 am, and an intraperitoneal glucose bolus ( $2 \mathrm{~g} / \mathrm{kg}$ body weight) was administered to conscious, unrestrained mice. During the GTT, blood glucose was measured at 30, 60 and $120 \mathrm{~min}$. Plasma insulin levels were analyzed using the LINCOplex mouse endocrine immunoassay panel following the manufacturer's instructions (Millipore, St. Charles, MO). 


\section{Pancreatic islet isolation}

Pancreatic islets were isolated from 12-week-old mice. After clamping the common bile duct as it joins the intestine, the pancreas was inflated with $5 \mathrm{ml}$ of collagenase type XI (0.6 mg/ml; Sigma-Aldrich, St. Louis, MO) diluted in Hanks balanced salt solution (HBSS; Sigma-Aldrich). The distended pancreas was removed and incubated at $37^{\circ} \mathrm{C}$ for $10 \mathrm{~min}$, and the islets were dispersed by gentle shaking. Enzymatic digestion was stopped by the addition of $45 \mathrm{ml}$ of cold HBSS containing 10\%FBS. Two rounds of centrifugation ( $300 \times \mathrm{g}$ for $2 \mathrm{~min}$ ) and washes with fresh HBSS/FBS were carried out, and the islets were resuspended in $10 \mathrm{ml}$ of HBSS/FBS buffer. The slurry was layered on top of a prepared histopaque gradient (comprised of a $10 \mathrm{ml}$ lower layer of Histopaque 1.119 , and $10 \mathrm{ml}$ upper layer of Histopaque 1.077; Sigma-Aldrich). Following centrifugation of the gradient at $1000 \times \mathrm{g}$ for $30 \mathrm{~min}$, the islets were collected from the top of the 1.077 interface, pipetted onto a $70 \mu \mathrm{m}$ cell strainer, and washed with HBSS/FBS buffer. Finally, the islets were rinsed into a Petri dish, isolated from any contaminating exocrine material visually using a dissecting microscope, and cultured in RPMI-1640 media (Cellgro, University of Miami, FL), supplemented with $10 \%$ FBS and $100 \mathrm{U} / \mathrm{ml}$ of penicillin, and $100 \mu \mathrm{g} / \mathrm{ml}$ of streptomycin at $37^{\circ} \mathrm{C}$ in $5 \% \mathrm{CO}_{2}$. Prior to all experiments, islets were cultured for $48 \mathrm{~h}$ in RPMI1640 media containing $11 \mathrm{mM}$ glucose, and reselected for use based on morphology as assessed with a dissection microscope.

\section{Glucose-stimulated insulin secretion assay}

Twenty-four hours prior to the secretion assay, islets were picked into 24-well inserts (Multiwell Insert System, 8.0 $\mu \mathrm{m}$ pore size; BD Biosciences, San Jose, CA) in groups of 10 similarly sized islets and cultured in $1 \mathrm{ml} /$ well RPMI1640. For the insulin secretion assay, Krebs-Ringer Bicarbonate (KRBH) Buffer was prepared (129 mM NaCl, 4.8 $\mathrm{mM} \mathrm{KCl}, 1.2 \mathrm{mM} \mathrm{KH}_{2} \mathrm{PO}_{4}, 1.2 \mathrm{mM} \mathrm{MgSO}_{4} .7 \mathrm{H}_{2} \mathrm{O}, 10 \mathrm{mM}$ HEPES, $2.5 \mathrm{mM} \mathrm{CaCl}_{2} .2 \mathrm{H}_{2} \mathrm{O}$ and $4.8 \mathrm{mM} \mathrm{NaHCO}_{3}$ ) and oxygenated for $15 \mathrm{~min}$ with $95 \% \mathrm{O}_{2} / 5 \% \mathrm{CO}_{2}$. Bovine serum albumin (fatty acid-free, Cat. No. A6003; SigmaAldrich) at a final concentration of $0.625 \%$ was added to the buffer, then the buffer was warmed to $37^{\circ} \mathrm{C}$ and $\mathrm{pH}$ adjusted to 7.4 with $5 \mathrm{M} \mathrm{NaOH}$. The islets were starved for one hour at $37^{\circ} \mathrm{C}$ in $\mathrm{KRBH}+1 \mathrm{mM}$ glucose (Cat. No. 99787-CI, Cellgro) by transferring the 24 -well insert from the RPMI-1640 culture media to a new 24-well plate containing $1 \mathrm{ml} /$ well $\mathrm{KRBH}+\mathrm{BSA}$ and $1 \mathrm{mM}$ glucose. The islets were transferred to the experimental plates containing $1 \mathrm{ml} /$ well of $\mathrm{KRBH}+\mathrm{BSA}$ and $1 \mathrm{mM}, 10 \mathrm{mM}$ and 16.7 $\mathrm{mM}$ glucose. Following a one-hour incubation at $37^{\circ} \mathrm{C}$, the insert containing the islets was removed and the buffer plate frozen at $-80^{\circ} \mathrm{C}$. The insulin ELISA was carried out using the Ultra Sensitive Mouse Insulin ELISA kit (Cat. No. 90080; Crystal Chem Inc. Downers Grove, IL). Five microliters of each buffer sample was run in duplicate per assay protocol.

\section{DNA and RT-PCR analysis}

DNA was isolated from tail tissue and used for PCR and direct sequencing analysis of the Nnt gene. RT-PCR using the One-Step System (Invitrogen, Carlsbad, CA) and islet RNA was performed using the oligonucleotides, Nnt forward-TACAAGAGCTGCCGCTTTGGA, and Nnt reverseAGACCCACTAAAGGTGACTCCG; the product was used for direct DNA sequencing.

\section{qRT-PCR}

RNA isolation kits from QIAGEN (micro-RNAeasy kit; Valencia, CA) were used to prepare RNA from purified islets with a final eluate of $15 \mu \mathrm{l}$ per mouse. RNA was quantified using Agilent's 2100 Bioanalyzer (Santa Clara, CA). Real time PCR was performed using $0.2 \mu \mathrm{M}$ of Plagl1 primer and probe (forward-TCAAGTGCTCGAAGGCTGAGT, reverse-TGTGTGGCCATGTGTCTCATC, probeFAM-TGGCAAAGCCTTCGTCTCCAAGTATAAGC-BHQ).

Primers were derived from different exons to avoid amplification of any residual genomic DNA. The RT-PCR reactions were done using QIAGEN's Quantitect Multiplex RT-PCR kit. The total reaction volume was $20 \mu \mathrm{l}$ per well and 20 ng RNA per reaction. Eight replicates of islets isolated from B6 and four replicates of BLKS were run with cyclophilin used as the housekeeping gene. Amplification and quantification of PCR products was performed on an ABI Prism 7900 (Applied Biosystems, Foster City, CA). Data were exported into Excel and analyzed using the delta CT method.

\section{Islet histology}

Pancreata were removed and fixed in buffered zinc formalin and embedded in paraffin. Pancreas sections $(5 \mu \mathrm{m})$ were deparaffinzed, hydrated and blocked for non-specific reactivity with CAS block (Zymed Lab., San Francisco, $\mathrm{CA})$. Sections were incubated with guinea pig anti-swine insulin (A562; DAKO, Carpinteria, CA) at 1:3000 for 45 min at room temperature. Insulin was detected by biotinylated goat anti-guinea pig (BA-7000; Vector Laboratories Inc., Burlingame $\mathrm{CA}$ ) at 1:100. Slides were quenched with $3 \% \mathrm{H}_{2} \mathrm{O}_{2}$ and followed with avidin-biotin HRP Complex (Vector Lab., Burlingame CA). Reaction sites were visualized with DAB (DAKO). Next, slides were rinsed with PBS thoroughly and incubated with rabbit anti-human glucagon (A565; DAKO) at 1:800 for $1 \mathrm{~h}$ at room temperature. Glucagon was detected by a biotinylated goat anti-rabbit secondary (BA-1000; Vector Lab.) at 1:200 and followed with avidin-biotin alkaline phosphatase complex. Reaction sites were visualized with alkaline phosphatase substrate (Vector Lab.). 


\section{Experimental design for islet expression profiling}

We investigated gene expression differences in islets from B6 and BLKS mice and between pretreatments in the presence of low $(5 \mathrm{mM})$ and high glucose $(20 \mathrm{mM})$ in the culture media (to simulate basal and stimulated conditions respectively). To provide $>85 \%$ confidence that each fold change $>1.5$ was true, we used $n=5$ per group. To eliminate differences in gene expression contributed by variation across mice within a group, we did not pool islets from different animals but kept them separate. Islets were then cultured separately for $24 \mathrm{~h}$ in RPMI-1640 media containing either $5 \mathrm{mM}$ or $20 \mathrm{mM}$ glucose. At the end of the culture pretreatment, the islets were picked from the culture vessel, rinsed briefly in HBSS/FBS buffer and homogenized in RLT buffer. RNA was prepared using the micro-RNAeasy kit (QIAGEN). On average, $580 \mathrm{ng}$ of total RNA was recovered from the isolated islets from each individual mouse.

\section{Pancreatic insulin content}

Pancreata were excised and frozen in liquid nitrogen and stored at $-80^{\circ} \mathrm{C}$. Protein content was determined using the BCA Protein Assay Kit (Thermo Scientific Rockford, IL) following homogenization of the pancreata for $2 \mathrm{~min}$ at $25 \mathrm{~Hz}$ in $1 \mathrm{ml}$ of $0.18 \mathrm{M} \mathrm{HCl}$ and $70 \%$ ETOH in a TissueLyser (Qiagen Gmbh, Germany). The tissue lysate was clarified for $10 \mathrm{~min}$ at $4000 \mathrm{rpm}$ and the supernatant was transferred to a fresh microcentrifuge tube. For the protein assay, the supernatant was $10 \times$ diluted in PBS. The insulin content assay was performed using Ultra Sensitive Mouse Insulin ELISA kit (Crystal Chem). The tissue lysate was diluted $1000 \times$ and $6000 \times$ with sample diluent supplied with the kit before running the assay. All samples for both assays were run in duplicate.

\section{Expression profiling}

Total RNA was profiled following the Agilent Two-Color Microarray-Based Gene Expression Analysis Protocol v4.0.2. Briefly, $200 \mathrm{ng}$ of total RNA from each sample was separately amplified and labeled with Cy3- and Cy5labeled CTP (Perkin Elmer; Wellesley, MA) using the Agilent low-input linear amplification kit. Labeled cRNA was purified using the Qiagen RNeasy Mini kit protocol for liquid samples (QIAGEN). Purified cRNA was quantified using the Nanodrop Fluorospectrometer ND-3000 (Wilmington, DE). Similar amounts of Cy3- and Cy5labeled cRNA were combined and fragmented for $30 \mathrm{~min}$ at $60^{\circ} \mathrm{C}$. The products were hybridized to Agilent Mouse Whole Genome Microarrays, and the resulting array data were extracted using Agilent Feature Extraction Software v8.1.

\section{Bioinformatic analysis}

Raw data for each array were analyzed with Matlab software (The Mathworks Inc. Natick, MA). Data were not analyzed as dye ratios, but as dye-normalized relative fluorescence units (RFUs). Dye normalization was accomplished by pairing Cy3 and Cy5 values, and determining the effect of dye on RFU magnitude by including dye as a factor in an ANOVA analysis of the binary logarithmtransformed probe intensities, including all two-factor interactions. The other factors in the ANOVA were strain and glucose pretreatment. Found to be significant, the effect of reporter dye was subtracted in a least-squares manner. Ultimately, technical and then biological replicates were averaged prior to fold-change calculations. Raw and normalized data discussed in this publication have been deposited in National Center for Biotechnology Information's Gene Expression Omnibus (GEO, http:// www.ncbi.nlm.nih.gov/geo/) and are accessible through GEO Series accession number GSE11257.

Genotyping data from Davis et al [9] were used to divide the genome into DBA and B6 regions. Each region is bordered by two markers for the same strain with no intervening markers of any other strain. Regions with informative SNPs, not attributable to DBA or B6 were labeled Other. Each microarray probe was mapped to a region by determining if its target gene overlapped with any identified region. Probes not mapped to one of the three regions above were labeled as Unmapped. Fold-change distributions of the four classes of probe were compared using the Kruskal-Wallis test, a nonparametric ANOVA testing the hypothesis that groups have the same median fold-change rank. Fold changes were calculated between BLKS and B6 mice under high-glucose conditions, and those with a strain effect $P$ value of $<1 E-6$ were used in the test. This test, for differences between regions, was executed for the entire genome and for each chromosome individually.

\section{Competing interests}

The authors declare that they have no competing interests.

\section{Authors' contributions}

AAA carried out the gene expression data analysis, the SNP analysis, and participated in drafting the manuscript. $\mathrm{JH}$ did the glucose tolerance testing, the insulin ELISA for islet insulin secretion experiment, the measurement of pancreatic insulin content, the Plagl1 qPCR, and the Nnt RT-PCR. TJ and CL performed the sequencing and related analysis. DJL prepared RNA from islets isolated by JM, $M G$, and DJL. DMB and MAD carried out the expression profiling. MMV participated in drafting the paper. DJL conceived of the study, participated in its design and coordination, performed experiments and their analysis, and participated in drafting the manuscript. All authors read and approved the final manuscript. 


\section{Additional material}

\section{Additional file 1}

Supplementary data. Figure showing location of the probes from the islet expression profiling compared to the genomic location of the contributing genomes. Table showing differences in gene expression between genomic regions (DBA, B6, Other, Unmapped) at the whole genome and chromosomal levels.

Click here for file

[http://www.biomedcentral.com/content/supplementary/17558417-2-1-S1.doc]

\section{Acknowledgements}

We would like to thank Dr Russ Cattley and Gwyneth Van for help with immunohistochemistry.

\section{References}

I. Bell GI, Polonsky KS: Diabetes mellitus and genetically programmed defects in beta-cell function. Nature 200I, 4|4:788-79I.

2. Stoehr JP, Nadler ST, Schueler KL, Rabaglia ME, Yandell BS, Metz SA, Attie AD: Genetic obesity unmasks nonlinear interactions between murine type 2 diabetes susceptibility loci. Diabetes 2000, 49:1946-1954.

3. Clee SM, Yandell BS, Schueler KM, Rabaglia ME, Richards OC, Raines SM, Kabara EA, Klass DM, Mui ET, Stapleton DS, Gray-Keller MP, Young MB, Stoehr JP, Lan H, Boronenkov I, Raess PW, Flowers MT, Attie AD: Positional cloning of Sorcs I, a type-2 diabetes quantitative trait locus. Nat Genet 2006, 38:688-693.

4. Gapp DA, Leiter EH, Coleman DL, Schwizer RW: Temporal changes in pancreatic islet composition in C57BL/6J-db/db (diabetes) mice. Diabetologia 1983, 25:439-443.

5. Leiter EH, Coleman DL, Hummel KP: The influence of genetic background on the expression of mutations at the diabetes locus in the mouse. III. Effect of $\mathbf{H - 2}$ haplotype and sex. Diabetes 1981, 30:1029-1034.

6. Kooptiwut S, Zraika S, Thorburn AW, Dunlop ME, Darwiche R, Kay TW, Proietto J, Andrikopoulos S: Comparison of insulin secretory function in two mouse models with different susceptibility to beta-cell failure. Endocrinology 2002, I 43:2085-2092.

7. Baetens D, Stefan Y, Ravazzola M, Malaisse-Lagae F, Coleman DL, Orci L: Alteration of islet cell populations in spontaneously diabetic mice. Diabetes 1978, 27: I-7.

8. Kaku K, Province M, Permutt MA: Genetic analysis of obesityinduced diabetes associated with a limited capacity to synthesize insulin in C57BL/KS mice: evidence for polygenic control. Diabetologia 1989, 32:636-643.

9. Davis RC, Schadt EE, Cervino AC, Peterfy M, Lusis AJ: Ultrafine mapping of SNPs from mouse strains C57BL/6J, DBA/2J, and C57BLKS/J for loci contributing to diabetes and atherosclerosis susceptibility. Diabetes 2005, 54: II91-II99.

10. Mao HZ, Roussos ET, Peterfy M: Genetic analysis of the diabetes-prone C57BLKS/] mouse strain reveals genetic contribution from multiple strains. Biochim Biophys Acta 2006, I 762:440-446.

II. Naggert JK, Mu JL, Frankel W, Bailey DW, Paigen B: Genomic analysis of the C57BL/Ks mouse strain. Mamm Genome 1995, 6:131-133.

12. Goren HJ, Kulkarni RN, Kahn CR: Glucose homeostasis and tissue transcript content of insulin signaling intermediates in four inbred strains of mice: C57BL/6, C57BLKS/6, DBA/2, and I29XI. Endocrinology 2004, I 45:3307-3323.

13. Zraika S, Aston-Mourney K, Laybutt DR, Kebede M, Dunlop ME, Proietto J, Andrikopoulos S: The influence of genetic background on the induction of oxidative stress and impaired insulin secretion in mouse islets. Diabetologia 2006, 49:I254-I 263.

14. Hekerman P, Zeidler J, Korfmacher S, Bamberg-Lemper S, Knobelspies $H$, Zabeau L, Tavernier J, Becker W: Leptin induces inflam- mation-related genes in RINm5F insulinoma cells. $B M C \mathrm{Mol}$ Biol 2007, 8:4I.

15. Homo-Delarche F, Calderari S, Irminger JC, Gangnerau MN, Coulaud J, Rickenbach K, Dolz M, Halban P, Portha B, Serradas P: Islet inflammation and fibrosis in a spontaneous model of type 2 diabetes, the GK rat. Diabetes 2006, 55: I625-1633.

16. Baekkeskov S, Aanstoot HJ, Christgau S, Reetz A, Solimena M, Cascalho M, Folli F, Richter-Olesen H, De Camilli P: Identification of the $64 \mathrm{~K}$ autoantigen in insulin-dependent diabetes as the GABA-synthesizing enzyme glutamic acid decarboxylase. Nature 1990, 347:I5I-I56.

17. Fanjul M, Renaud W, Merten M, Guy-Crotte O, Hollande E, Figarella C: Presence of MRP8 and MRPI4 in pancreatic cell lines: differential expression and localization in CFPAC-I cells. $\mathrm{Am} J$ Physiol 1995, 268:CI24I-I25I.

18. Schnekenburger J, Schick V, Kruger B, Manitz MP, Sorg C, Nacken W, Kerkhoff C, Kahlert A, Mayerle J, Domschke W, Lerch MM: The calcium-binding protein SI00A9 is essential for pancreatic leukocyte infiltration and induces disruption of cell-cell contacts. J Cell Physiol 2008, 2 I 6:558-567.

19. Ikemoto M, Matsumoto S, Egawa H, Okitsu T, Iwanaga Y, Umemoto $\mathrm{S}$, Itoh $\mathrm{H}$, Murayama $\mathrm{H}$, Fujita $\mathrm{M}$ : A case with transient increases in serum SI00A8/A9 levels implying acute inflammatory responses after pancreatic islet transplantation. Ann Clin Biochem 2007, 44:570-572.

20. Salehi A, Meidute Abaraviciene S, Jimenez-Feltstrom J, Ostenson CG, Efendic S, Lundquist I: Excessive islet NO generation in type 2 diabetic GK rats coincides with abnormal hormone secretion and is counteracted by GLP-I. PLOS ONE 2008, 3:e2 I65.

21. Chen J, Saxena G, Mungrue IN, Lusis AJ, Shalev A: Thioredoxininteracting protein: a critical link between glucose toxicity and beta-cell apoptosis. Diabetes 2008, 57:938-944.

22. Parikh H, Carlsson E, Chutkow WA, Johansson LE, Storgaard $H$, Poulsen P, Saxena R, Ladd C, Schulze PC, Mazzini MJ, Jensen CB, Krook $A$, Björnholm $M$, Tornqvist $H$, Zierath JR, Ridderstråle $M$, Altshuler D, Lee RT, Vaag A, Groop LC, Mootha VK: TXNIP regulates peripheral glucose metabolism in humans. PLoS Med 2007, 4:el58.

23. Benjamini $Y$, Hochberg $Y$ : Controlling the false discovery rate: $a$ practical and powerful approach to multiple testing. J R Stat Soc Ser B 1995, 57:289-300.

24. Yamaguchi $H$, Igarashi $M$, Hirata $A$, Tsuchiya $H$, Sugiyama $K$, Morita $Y$, Jimbu $Y$, Ohnuma H, Daimon M, Tominaga M, Kato T: Progression of diabetic nephropathy enhances the plasma osteopontin level in type 2 diabetic patients. Endocr J 2004, 5 I:499-504.

25. Arafat HA, Katakam AK, Chipitsyna G, Gong Q, Vancha AR, Gabbeta J, Dafoe DC: Osteopontin protects the islets and beta-cells from interleukin-I beta-mediated cytotoxicity through negative feedback regulation of nitric oxide. Endocrinology 2007, | 48:575-584.

26. Johansson F, Kramer F, Barnhart S, Kanter JE, Vaisar T, Merrill RD, Geng L, Oka K, Chan L, Chait A, Heinecke JW, Bornfeldt KE: Type I diabetes promotes disruption of advanced atherosclerotic lesions in LDL receptor-deficient mice. Proc Natl Acad Sci USA 2008, I05:2082-2087.

27. Gunton JE, Kulkarni RN, Yim S, Okada T, Hawthorne WJ, Tseng YH, Roberson RS, Ricordi C, O'Connell PJ, Gonzalez FJ, Kahn CR: Loss of ARNT/HIF I beta mediates altered gene expression and pancreatic-islet dysfunction in human type 2 diabetes. Cell 2005, I 22:337-349.

28. Fischer-Lindahl K: On naming $\mathbf{H} \mathbf{2}$ haplotypes: functional significance of MHC class Ib alleles. Immunogenetics 1997, 46:53-62.

29. Kamiya M, Judson H, Okazaki Y, Kusakabe M, Muramatsu M, Takada S, Takagi N, Arima T, Wake N, Kamimura K, Satomura K, Hermann $R$, Bonthron DT, Hayashizaki Y: The cell cycle control gene ZAC/ PLAGLI is imprinted - a strong candidate gene for transient neonatal diabetes. Hum Mol Genet 2000, 9:453-460.

30. Ma D, Shield JP, Dean W, Leclerc I, Knauf C, Burcelin RR, Rutter GA, Kelsey G: Impaired glucose homeostasis in transgenic mice expressing the human transient neonatal diabetes mellitus locus, TNDM. J Clin Invest 2004, I I 4:339-348.

31. Abdollahi A: LOTI (ZACI/PLAGLI) and its family members: mechanisms and functions. J Cell Physiol 2007, 2 1 0: I 6-25.

32. Toye AA, Lippiat JD, Proks P, Shimomura K, Bentley L, Hugill A, Mijat V, Goldsworthy M, Moir L, Haynes A, Quarterman J, Freeman HC, Ashcroft FM, Cox RD: A genetic and physiological study of 
impaired glucose homeostasis control in C57BL/6J mice. Diabetologia 2005, 48:675-686.

33. Freeman H, Shimomura K, Cox RD, Ashcroft FM: Nicotinamide nucleotide transhydrogenase: a link between insulin secretion, glucose metabolism and oxidative stress. Biochem Soc Trans 2006, 34:806-8I0.

34. Freeman HC, Hugill A, Dear NT, Ashcroft FM, Cox RD: Deletion of nicotinamide nucleotide transhydrogenase: a new quantitative trait locus accounting for glucose intolerance in C57BLI 6J mice. Diabetes 2006, 55:2153-2I56.

35. Freeman H, Shimomura K, Horner E, Cox RD, Ashcroft FM: Nicotinamide nucleotide transhydrogenase: a key role in insulin secretion. Cell Metab 2006, 3:35-45.

36. Aston-Mourney K, Wong N, Kebede M, Zraika S, Balmer L, McMahon JM, Fam BC, Favaloro J, Proietto J, Morahan G, Andrikopoulos S: Increased nicotinamide nucleotide transhydrogenase levels predispose to insulin hypersecretion in a mouse strain susceptible to diabetes. Diabetologia 2007, 50:2476-2485.

37. Mu JL, Naggert JK, Svenson KL, Collin GB, Kim JH, McFarland C, Nishina PM, Levine DM, Williams KJ, Paigen B: Quantitative trait loci analysis for the differences in susceptibility to atherosclerosis and diabetes between inbred mouse strains C57BL/ 6J and C57BLKS/J. J Lipid Res 1999, 40:1328-1335.

Publish with Bio Med Central and every scientist can read your work free of charge

"BioMed Central will be the most significant development for disseminating the results of biomedical research in our lifetime. "

Sir Paul Nurse, Cancer Research UK

Your research papers will be:

- available free of charge to the entire biomedical community

- peer reviewed and published immediately upon acceptance

- cited in PubMed and archived on PubMed Central

- yours - you keep the copyright

Submit your manuscript here:

http://www.biomedcentral.com/info/publishing_adv.asp
BiolMedcentral 